\title{
KERAGAAN TEDS TYPE SUPER SHOOTER PADA TRAWL UDANG YANG BEROPERASI DI LAUT ARAFURA
}

\author{
Agustinus Anung Widodo') dan Mahiswara ${ }^{2)}$ \\ 1) Peneliti pada Pusat Riset Perikanan Tangkap, Ancol-Jakarta \\ 2) Peneliti pada Balai Riset Perikanan Laut, Muara Baru-Jakarta \\ Teregristrasi I tanggal: 1 Agustus 2007; Diterima setelah perbaikan tanggal: 11 Maret 2008; \\ Disetujui terbit tanggal: 31 Maret 2008
}

\begin{abstract}
ABSTRAK
Arafura merupakan satu-satunya daerah penangkapan trawl udang di Indonesia sesuai yang direkomendasikan melalui Keputusan Presiden No.85 tahun 1982 terkait peraturan pengoperasian trawl udang di Indonesia. Salah satu butir penting pada Keputusan Presiden tersebut adalah trawl udang dilengkapi alat pereduksi hasil tangkap sampingan ikan atau alat pemisah ikan. TEDs type super shooter merupakan alat pemisah ikan yang saat ini direkomendasikan penggunaannya oleh Departemen Kelautan dan Perikanan. Dalam rangka mengetahui kinerja TEDs type super shooter pada trawl udang di Indonesia, pada bulan Juli sampai dengan Agustus 2003 telah dilakukan penelitian melalui ujicoba pada kapal trawler double 180,17 GT milik PT. Nusantara Fisheries yang beroperasi di Laut Arafura. Kinerja TEDs type super shooter dalam hal ini meliputi efektivitas mereduksi bycatch (ikan dan penyu) dan tingkat reduksi hasil tangkapan udang secara kuantitatif. Hasil penelitian menunjukkan bahwa pemasangan TEDs pada trawl udang mampu mereduksi bycatch ikan rata-rata $38,34 \%$ dan penyu $100 \%$. Di sisi pemasangan, TEDs mengurangi hasil tangkapan utama yaitu udang rata-rata $18,43 \%$ dari total tangkapan.
\end{abstract}

KATAKUNCI: $\quad T E D s$, trawl udang, Laut Arafura

ABSTRACT: The performance of TEDs type super shooter on shrimp trawl operated in Arafura Sea. By: Agustinus Anung Widodo and Mahiswara

Arafura was only the shrimp trawl ground that recommended in accordance with the President Decree No.85 Year of 1982 regarding the shrimp trawl operating in Indonesia. One of the important content of that decree, the shrimp trawl must be equiped by the bycatch excluder devices. The kind of the bycatch excluder devices that recommended by Indonesian Ministry of Marine Affairs and Fisheries is TEDs type super shooter. In order to understand the performance of turtle excluder devices TEDs type super shooter on the commercial shrimp trawling, a research was carried out on July until August 2003 through experimental fishing by using a double rig trawler 180.17 GT, belonging to Nusantara Fisheries, a private shrimp fishing company. The performance of TEDs type super shooter in this case covered the effectiveness in reducing bycatch (fish and sea turtle) and retaining rate of shrimp. The result show that TEDs type super shooter reduced bycatch (fish) $38.34 \%$ and turtle $100 \%$ in average, but in other hand the loss of shrimp was $18.43 \%$ in average of total catch.

KEYWORDS: TEDs, shrimp trawl, Arafura Sea

\section{PENDAHULUAN}

Trawl adalah alat penangkap ikan yang bahan utamanya terbuat dari jaring berbentuk kerucut (cone shape net) dengan salah satu ujung terbuka besar sebagai mulut dan semakin kecil ke ujung lain sebagai kantong yang dapat dibuka dan ditutup. Jenis trawl yang umum dioperasikan di Indonesia adalah jenis traw/ dasar. Trawl dasar dioperasikan dengan cara dihela sepanjang dasar perairan dengan kecepatan dan jangka waktu tertentu. Tujuan pengoperasian traw/dasar adalah untuk menangkap ikan-ikan dasar (Nedelec et al., 1990; FAO, 1995a). Mulut jaring dapat terbuka melebar (horizontal) dengan bantuan papan pembuka (siwakan, otter board) yang diikatkan pada ke-2 sisi mulut. Adapun untuk tujuan pembukaan tegak (vertical) mulut jaring dipasang sejumlah pelampung pada tali pelampung (head rope) dan sejumlah pemberat pada tali pemberat (ground rope) (FAO, 1995a). Dengan mulut terbuka lebar selama dihela, jaring akan menelan semua benda (termasuk ikan) yang dilewati. Oleh karena itu, alat tangkap traw/ digolongkan sebagai alat tangkap yang sangat tidak selektif. Gambar 1 menunjukkan keragaan dan bagian-bagian utama trawl.

Karena karakter tersebut, pengoperasian traw/di Indonesia dilarang melalui Keputusan Presiden No.39 tahun 1980. Selanjutnya, melalui Keputusan Presiden No.85 tahun 1982 (Departemen Pertanian, 1987) 
keberadaan traw/diganti dengan pukat udang. Pada tulisan ini istilah pukat udang disebut sebagi trawl udang (shrimp trawl). Trawludang adalah jaring trawl yang dilengkapi dengan alat pemisah ikan yang merupakan terjemahan dari bycatch excluder device dengan sasaran utama untuk menangkap udang. Pada trawludang, ikan merupakan hasil tangkap sampingan (by catch) terbesar selain biota lain seperti hal penyu.

Terdapat berbagai tipe alat pemisah ikan yang selama ini lazim digunakan pada traw/udang. Adapun alat pemisah ikan yang saat ini direkomendasikan untuk digunakan pada pukat udang di Indonesia adalah TEDs type super shooter untuk menggantikan TEDs type rigid hooped yang sebelumnya telah digunakan sebagai alat pemisah ikan sejak tahun 1982. TEDs adalah turtle excluder devices, yang sejatinya adalah alat yang berfungsi sebagai pelolos penyu laut (sea turtle) yang tertangkap jaring trawl. Selanjutnya, di Indonesia fungsi TEDs type super shooter juga sebagai perangkat pelolos ikan karena alat ini juga mampu mereduksi tangkapan ikan hasil tangkap sampingan (by catch) pada trawl udang di Indonesia. TEDs type super shooter merupakan hasil penemuan para peneliti teknologi atat tangkap ikan dari National Marine Fisheries Service-NOOAAmerika Serikat.

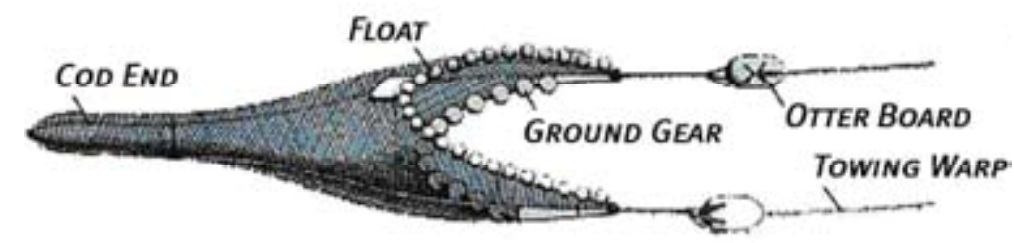

Gambar 1. Ilustrasi keragaan dan bagian-bagian utama trawl.

Figure 1. Illustration of trawl permormance and the principal part of trawl.

Sebelum direkomendasikan penggunaannya, tahun 1996 para peneliti National Marine Fisheries Service-NOOAAmerika Serikat melakukan introduksi TEDs type super shooter dan uji coba di Laut Jawa. Setelah lebih dari 5 tahun implemetasi, maka pada tahun 2003 dilakukan penelitian penggunaan TEDs type super shooter pada kapal trawl udang yang beroperasi di perairan Arafura. Tujuan penelitian ini adalah mengetahui keragaan pukat udang yang dilengkapi TEDs type super shooter. Keragaan TEDs type super shooteryang dimaksud meliputi efektivitas mereduksi by catch (ikan dan penyu) dan tingkat reduksi hasil tangkapan udang secara kuantitatif.

\section{BAHAN DAN METODE}

Penelitian dilaksanakan bulan Juli sampai dengan Agustus 2003 di perairan Arafura (Gambar 2). Kedalaman perairan lokasi riset antara 15 sampai dengan $35 \mathrm{~m}$ dengan jenis dasar perairan berupa lumpur berpasir.

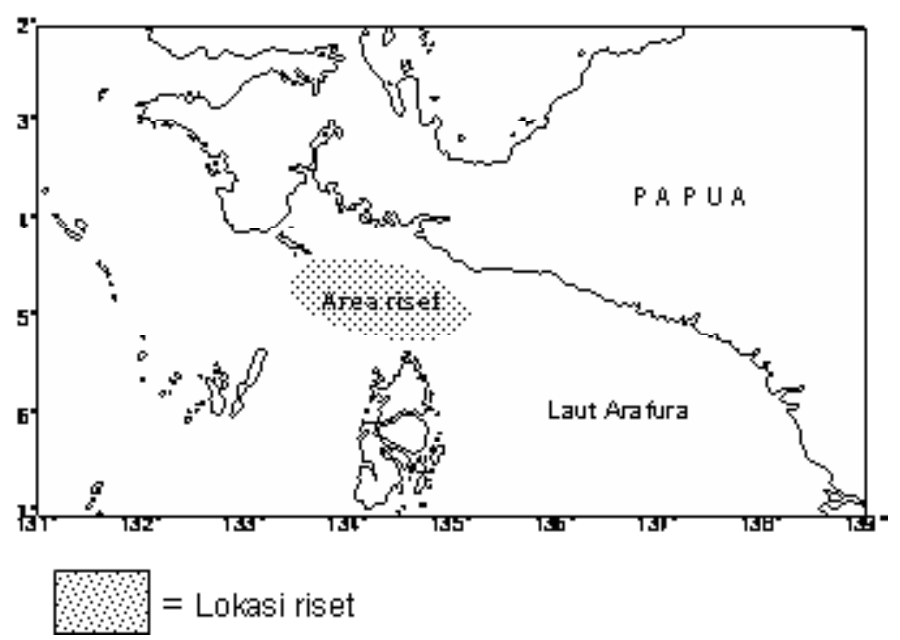

Gambar 2. Figure 2. Lokasi riset ujicoba TEDs tipe super shooter. Research location of trial of TEDs type super shooter 
Kapal yang digunakan pada penelitian ini adalah kapal traw/udang K.M. Nusantara Perdana milik P.T. Nusantara Fisheries yang melakukan operasi penangkapan di perairan Laut Arafura dan sekitar. Dimensi utama kapal adalah panjang (Loa) 30,70 m, lebar (B) 7,00 m, dan dalam (D) 3,20 m atau 180,17 GT dengan produksi Daihatsu Diesel 600 HP. Kapasitas palka udang 30 ton. Jumlah anak buah kapal 19 orang.

Jaring trawl udang yang digunakan mempunyai desain dan konstruksi utama sebagai berikut, jaring trawludang dengan 4 potongan (four sheam type trawl) dengan headrope dan grom atau rope 26,60 m dan $31,40 \mathrm{~m}$. Badan jaring berupa jaring PE 380D/24-D/ 30 dan PE 380D/45 pada bagian kantong. Ukuran mata jaring bagian badan $60 \mathrm{~mm}$ dan bagian kantong $45 \mathrm{~mm}$. Pada headrope dilengkapi 3 palampung fiberglass ukuran $180 \mathrm{~mm}$ dan pada ground rope dilengkapi rantai pengejut (tickler chain). Jaring ini dilengkapi papan pembuka (otter board) dari bahan kayu ukuran panjang 2,60 m dan lebar 1,15 m (Gambar 3).

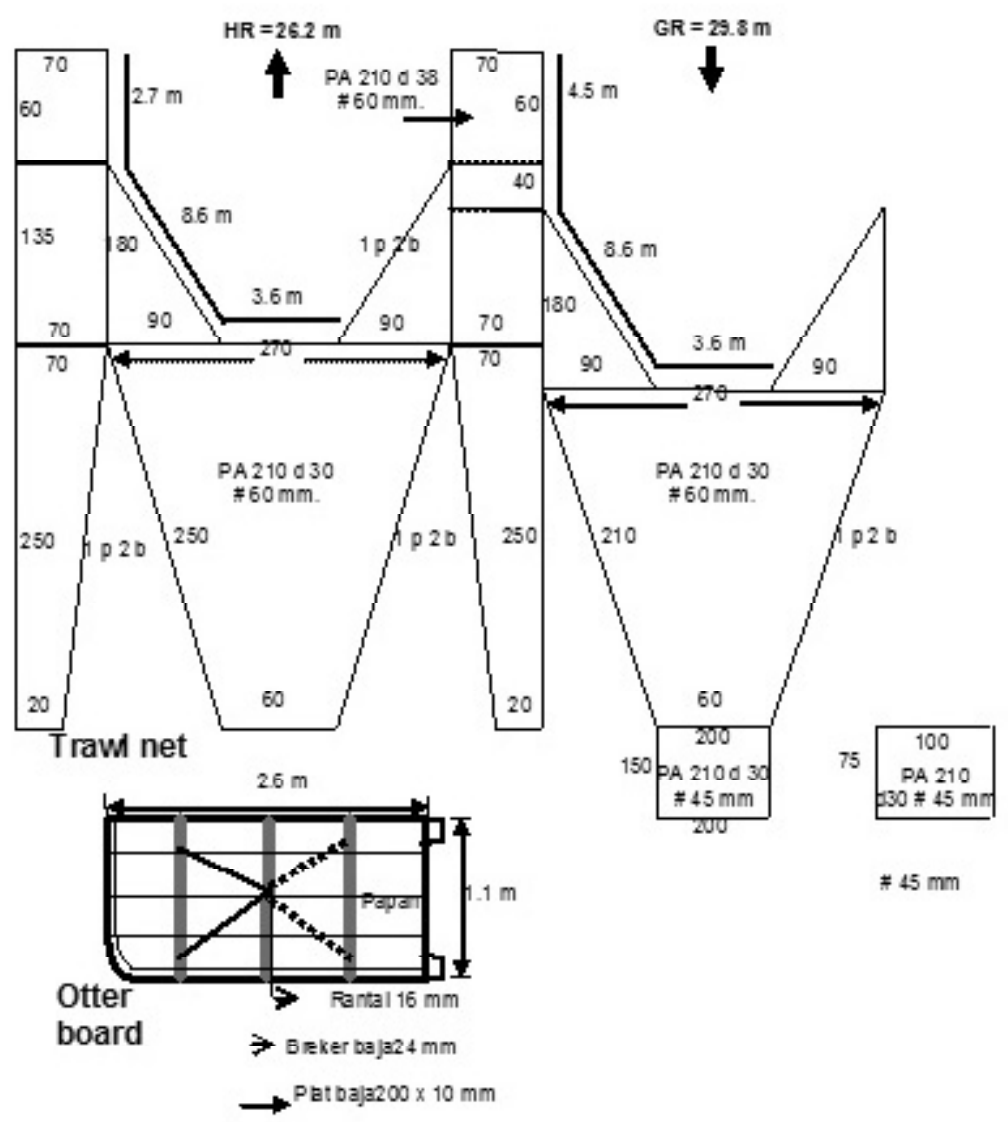

Gambar 3. Desain dan konstruksi jaring pukat udang K.M. Nusantara Perdana.

Figure 3. Design and construction of shrimp trawl M. V. Nusantara Perdana.

TEDs type super shooter yang diujicobakan mempunyai desain dan konstruksi seperti yang direkomendasikan NMFS. Terbuat dari bahan pipa aluminium, bingkai luar (outer frame) berbentuk oval dengan ukuran tinggi 51 inci $(129 \mathrm{~cm})$ dan lebar 42 inci $(106 \mathrm{~cm})$. Diameter pipa bingkai $3 / 4$ inci $(1,9 \mathrm{~cm})$, dimeter pipa kisi-kisi (grid bars) 5/8 inci $(1,6 \mathrm{~cm})$ dan jarak antar kisi-kisi 4 inci $(10 \mathrm{~cm})$ (Gambar 4).

Riset dilakukan melalui ujicoba (experimental fishing) 37 kali tawur (setting-hauling) jaring pada siang dan malam hari. Ujicoba dilakukan pada K.M.
Nusantara Perdana, adalah double rig trawler, yaitu trawler yang mengoperasikan sepasang jaring trawl. TEDs type super shooter dipasang pada salah satu jaring traw/ dan satu jaring lain tidak dipasang. Cara pemasangan TEDs ditunjukkan pada Gambar 5 dan 6. TEDs type super shooter yang berfungsi sebagai kontrol.

Analisis data, rata-rata hasil tangkapan sasaran (udang) pada jaring yang dipasang TEDs type super shooter dan jaring kontrol diperbandingkan secara 
deskriptif. Adapun tingkat kelolosan hasil tangkapan sasaran dihitung dengan rumus:

Tingkat kelolosan $=\quad \sum$ Ikan Lolos $\times 100 \%$

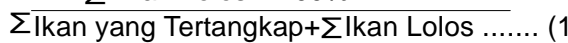

\section{HASIL DAN BAHASAN}

\section{Konsep Kerja TEDs}

TEDs type super shooter berupa kerangka kisikisi (separator grids) dipasang di dalam jaring trawl antara lain badan dan kantong (bagian di mana kecepatan air melemah). Konsep teknologi TEDs type super shooter adalah memanfaatkan perbedaan kecepatan renang ikan dan udang yang melewati lorong badang trawl. Pada umumnya ikan mampu berenang lebih cepat daripada udang (Taylor et al., 1985; Waston et al., 1986; Alverson et al., 1994. Ikan, udang, biota laut terutama penyu (sea turtle), dan benda-benda lain akan melewati corong dan kisi-kisi sebelum masuk ke dalam kantong (Gambar 7). Sebagian dari ikan, udang, dan biota lain yang berukuran tebal atau lebar $>10 \mathrm{~cm}$ dipastikan akan tersaring kisi-kisi TEDs type super shooter yang selanjutnya keluar melalui lubang pelepasan (escape hole) yang tersedia. Udang sebagai target tangkapan yang ikut keluar diupayakan agar semakin sedikit atau tidak ada udang yang lolos dari TEDs type super shooter.
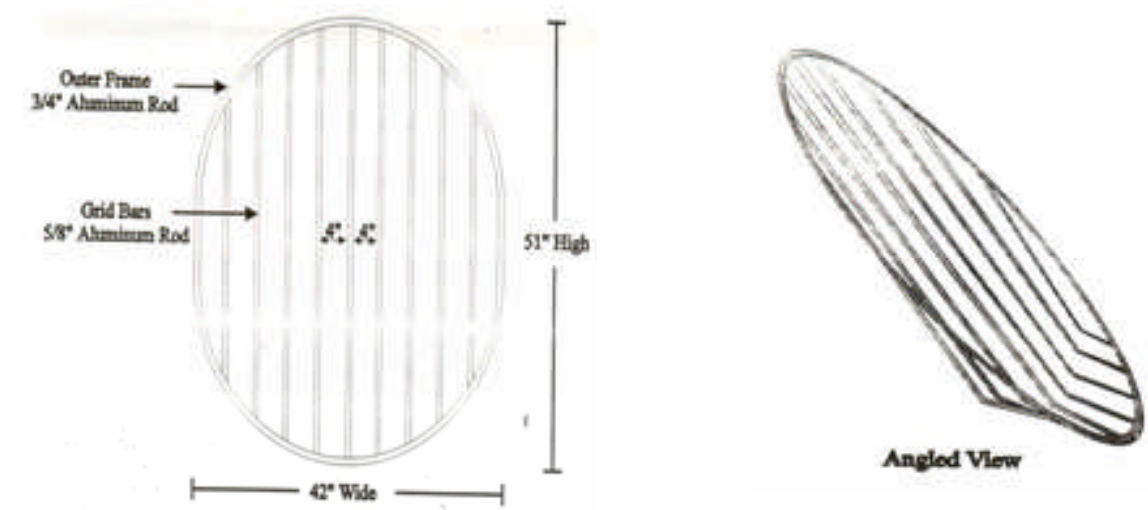

Gambar 4. Desain dan konstruksi TEDs type super shooter yang diujicoba.

Figure 4. Design and constructiion of TEDs type super shooter.

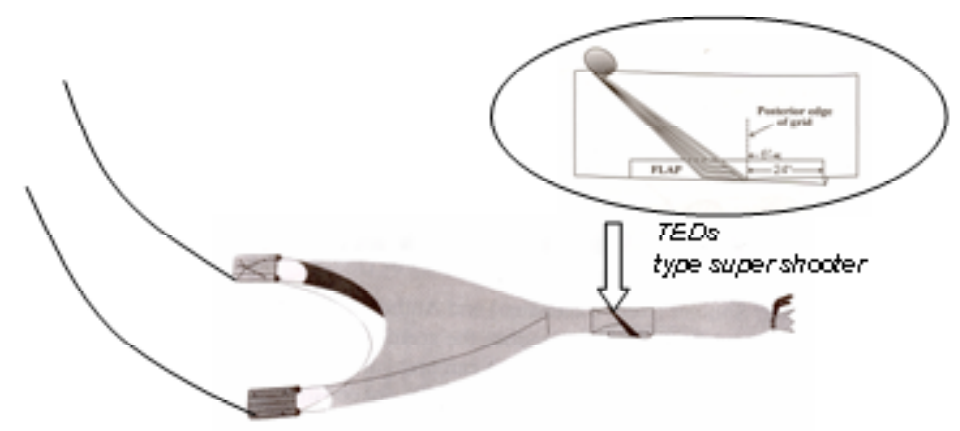

Gambar 5. Posisi pemasangan TEDs type super shooter pada pukat udang.

Figure 5. Equipment position of TEDs type super shooter on the shrimp trawl

\section{Hasil Tangkapan}

Hasil tangkapan trawl udang terdiri atas udang sebagai target utama, ikan dan biota laut lain sebagai hasil tangkap samping (bycatch).

\section{Catch Per Unit of Effort}

Catch per unit of effort adalah jumlah hasil tangkapan yang diperoleh per unit upaya (dalam hal ini towing). Hasil pengamatan terhadap 37 kali pengoperasian trawl (towing), di mana lama menghela jaring (towing duration) berkisar 110 sampai dengan 130 menit atau rata-rata 120 menit menunjukkan bahwa catch per unit of effort 1 trawl udang contoh (K.M. Nusantara Perdana) yang tidak dilengkapi TEDs type super shooter rata-rata $372,5 \mathrm{~kg}$ per towing. Jika keadaan normal, maka hasil tangkapan double rigger trawl sekitar $745 \mathrm{~kg}$ per towing atau 2 kali rata-rata hasil 1 trawl. Sedangkan jika trawl dilengkapi TEDs 
type super shooter, pada keadaan normal maka sepasang akan menangkap rata-rata sekitar 5.602 kg per towing (Tabel 1).

Selama penelitian berhasil teridentifikasi sekitar 45 famili ikan yang didominasi oleh jenis petek (Famili Leiogntida) yaitu lebih dari 44\%. Adapun udang sebagai sasaran utama penangkapan rata-rata tak lebih 7\% dari total tangkapan (Gambar 8).

\section{Sasaran Utama (Species Target) Penangkapan}

Sasaran utama penangkapan trawludang adalah udang. Jenis udang hasil tangkapan didominasi oleh tiger shrimp (Penacus semisulcatus), sedangkan udang banana (Penaeus merguensis) tertangkap lebih sedikit dibanding tiger shrimp. Jenis udang lain yang juga tertangkap meliputi black tiger (Penaeus monodon), king shrimp (Penaeus latisulcatus), dan blue tail (Metapenacus endeavouri). Tabel 1 menunjukkan udang hasil tangkapan trawl dengan TEDs type super shooter dan tanpa TEDs type super shooter. Dari Tabel 2 terlihat bahwa hasil tangkapan udang traw/tanpa TEDs type super shooterselalu lebih banyak (rata-rata 21,7 kg per towing) dibanding tangkapan udang dengan trawlyang dipasangi TEDs type super shooter (rata-rata 17,7 kg per towing). Tingkat kelolosan udang yang diakibatkan pemasangan TEDs type super shooter pada trawl udang mencapai $4,0 \mathrm{~kg}$ per towing atau $18,43 \%$.
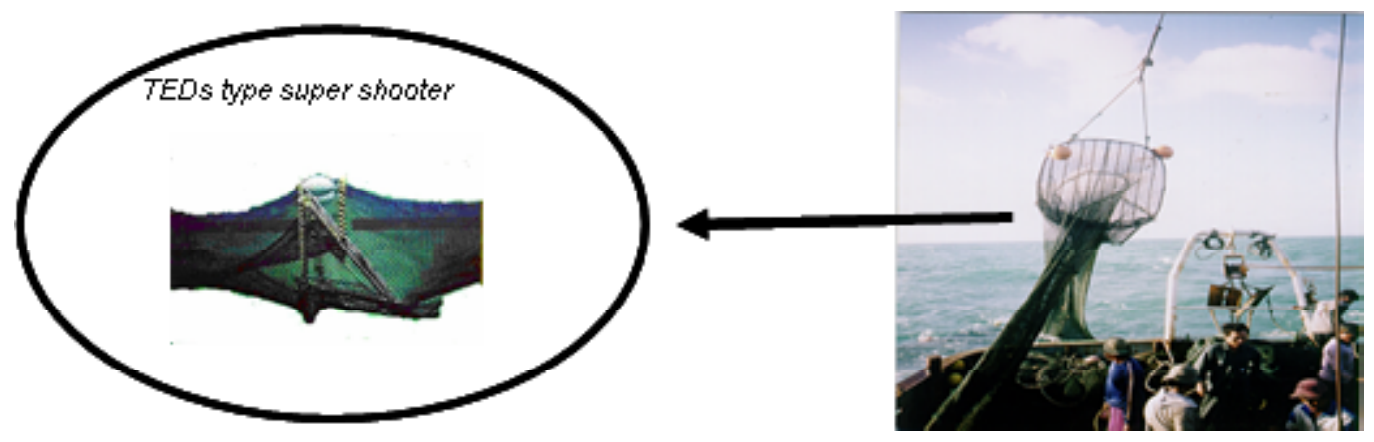

Gambar 6. Figure 6.

TEDs type super shooter terpasang pada traw/udang dalam rangka uji coba. Shrimp trawl equiped by the TEDs type super shooter.

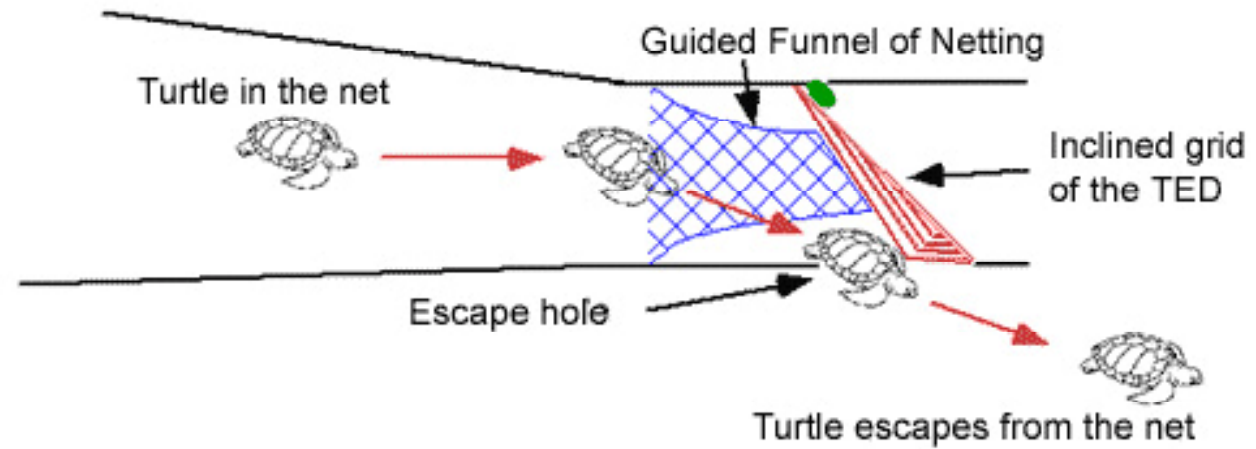

Gambar 7. Ilutrasi penyu lolos dari lubang keluaran TEDs tipe super shooter. Figure 7. The illustration turtle escapement on TEDs type super shooter.

Ikut lolos hasil tangkapan sasaran (udang) ratarata $4,0 \mathrm{~kg}(18,43 \%)$ per jam towing pada trawlyang dilengkapi TEDs type super shooter secara statistik tidak mengakibatkan perbedaan rata-rata hasil tangkapan trawl yang tidak dilengkapi TEDs type super shooter, namun kenyataan hilang 4,0 kg per jam towing trawlcukup banyak. Secara kumulatif, dari pengamatan 37 towing kehilangan hasil tangkapan udang mencapai $148 \mathrm{~kg}$. Tinggi tingkat kelolosan udang tersebut diduga diakibatkan oleh desain, konstruksi dan pemasangan TEDs type super shooter pada jaring trawl di Indonesia belum sesuai. Oleh karena itu, diperlukan pengamatan mendalam terkait desain, konstruksi, dan cara pemasangan TEDs type super shooter pada trawl udang sehingga tingkat kelolosan udang dapat dieliminir. 


\section{Hasil Tangkapan Samping (By Catch)}

\section{Ikan}

Hasil tangkapan samping (by catch) adalah bagian hasil tangkapan dari suatu unit penangkapan yang tertangkap bersama spesies sasaran. Pengamatan terhadap hasil tangkapan samping ikan menunjukkan bahwa trawl tanpa TEDs type super shooter menangkap rata-rata $350,78 \mathrm{~kg}$ per towing dan trawl yang dilengkapi TEDs type super shooter menangkap $213,63 \mathrm{~kg}$ per towing. Perbedaan dari ke-2 jenis trawl adalah $137,15 \mathrm{~kg}$ per towing atau $39,10 \%$ yang dapat diartikan sebagai tingkat efektivitas (tingkat kelolosan)

Tabel 1. Hasil tangkapan per towing (kg per towing) traw/udang yang tidak dilengkapi TEDs dan yang dilengkapi TEDs

Table 1. Catch per towing of shrimp trawl that unequiped and equiped by TEDs

\begin{tabular}{|c|c|c|c|c|c|c|}
\hline \multirow[t]{2}{*}{$\begin{array}{l}\text { No. } \\
\text { Towing }\end{array}$} & \multicolumn{3}{|c|}{$\begin{array}{c}\text { Hasil tangkapan } 1 \text { trawl tanpa TEDs/ } \\
\text { Catch per towing without TEDs } \\
\text { (kg per towing) }\end{array}$} & \multicolumn{3}{|c|}{$\begin{array}{c}\text { Hasil tangkapan } 1 \text { trawl dengan TEDs/ } \\
\text { Catch per towing with TEDs } \\
\text { (kg per towing) }\end{array}$} \\
\hline & Ikan/Fish & Udang/Shrimp & Total & Ikan/Fish & Udang/Shrimp & Tota \\
\hline 1 & 187,8 & 21,8 & 209,6 & 125,3 & 18,0 & 143,3 \\
\hline 2 & 205,9 & 24,4 & 230,3 & 112,3 & 17,2 & 129,5 \\
\hline 3 & 180,9 & 14,3 & 195,2 & 119,3 & 13,9 & 133,1 \\
\hline 4 & 325,0 & 12,9 & 337,9 & 170,0 & 8,2 & 178,2 \\
\hline 5 & 335,6 & 16,9 & 352,5 & 207,0 & 13,6 & 220,6 \\
\hline 6 & 415,1 & 29,7 & 444,8 & 213,3 & 21,5 & 234,8 \\
\hline 7 & 575,5 & 15,6 & 591,1 & 368,0 & 11,4 & 379,4 \\
\hline 8 & 255,5 & 24,6 & 280,1 & 138,1 & 15,7 & 153,8 \\
\hline 9 & 290,3 & 25,1 & 315,4 & 100,7 & 16,2 & 116,9 \\
\hline 10 & 404,1 & 20,6 & 424,7 & 196,7 & 18,2 & 214,9 \\
\hline 11 & 486,5 & 24,1 & 510,6 & 342,9 & 16,9 & 359,8 \\
\hline 12 & 648,5 & 19,3 & 667,8 & 411,8 & 17,8 & 429,5 \\
\hline 13 & 451,0 & 15,4 & 466,4 & 245,4 & 12,0 & 257,4 \\
\hline 14 & 391,0 & 8,9 & 399,9 & 218,0 & 7,0 & 225,0 \\
\hline 15 & 429,0 & 20,8 & 449,8 & 226,0 & 15,1 & 241,1 \\
\hline 16 & 378,4 & 18,7 & 397,1 & 262,5 & 14,1 & 276,6 \\
\hline 17 & 441,2 & 24,3 & 465,5 & 298,6 & 20,0 & 318,6 \\
\hline 18 & 724,4 & 32,5 & 756,9 & 407,2 & 24,6 & 431,8 \\
\hline 19 & 312,8 & 19,5 & 332,3 & 222,9 & 12,8 & 235,7 \\
\hline 20 & 543,6 & 29,1 & 572,7 & 300,6 & 20,2 & 320,8 \\
\hline 21 & 199,7 & 14,3 & 214,0 & 180,0 & 11,8 & 191,8 \\
\hline 22 & 268,3 & 19,7 & 288,0 & 198,5 & 13,3 & 211,8 \\
\hline 23 & 316,9 & 20,3 & 337,2 & 233,7 & 16,5 & 250,2 \\
\hline 24 & 414,7 & 37,1 & 451,8 & 279,5 & 30,8 & 310,3 \\
\hline 25 & 160,8 & 12,4 & 173,2 & 110,3 & 9,1 & 119,4 \\
\hline 26 & 300,7 & 25,1 & 325,8 & 127,7 & 20,1 & 147,8 \\
\hline 27 & 410,1 & 11,8 & 421,9 & 200,2 & 9,4 & 209,6 \\
\hline 28 & 176,5 & 27,1 & 203,6 & 90,8 & 20,7 & 111,5 \\
\hline 29 & 500,9 & 38,8 & 539,7 & 311,6 & 31,2 & 342,8 \\
\hline 30 & 175,3 & 21,8 & 197,1 & 120,1 & 16,4 & 136,5 \\
\hline 31 & 378,9 & 22,1 & 401,0 & 297,6 & 15,5 & 313,1 \\
\hline 32 & 190,4 & 18,7 & 209,1 & 157,1 & 15,0 & 172,1 \\
\hline 33 & 430,8 & 27,4 & 458,2 & 260,5 & 19,1 & 279,6 \\
\hline 34 & 186,7 & 15,5 & 202,2 & 110,8 & 12,6 & 123,4 \\
\hline 35 & 231,6 & 19,5 & 251,1 & 140,7 & 14,0 & 154,7 \\
\hline 36 & 490,1 & 36,3 & 526,4 & 298,5 & 30,4 & 328,9 \\
\hline 37 & 164,4 & 17,1 & 181,5 & 100,2 & 10,2 & 110,4 \\
\hline $\begin{array}{c}\text { Rata-rata/ } \\
\text { Average }\end{array}$ & 350,8 & 21,7 & 372,5 & 213,6 & 17,7 & 230,1 \\
\hline
\end{tabular}

TEDs type super shooter dalam mereduksi hasil tangkapan samping ikan (Tabel 3).

Adapun perbandingan antara hasil tangkapan samping ikan dan tangkapan utama (udang) adalah 9,35:1 pada traw/udang yang tidak dilengkapi TEDs type super shooter. Sedangkan pada traw/udang yang dilengkapi TEDs type super shooterperbandingan hasil tangkapan samping dan tangkapan utama (udang) menurun menjadi 9,20:1 (Tabel 4).

\section{Penyu}

Penyu laut (turtle) sering juga termasuk ke dalam hasil tangkapan samping dan kalau tertangkap dibuang dalam keadaan mati atau hidup. Tertangkap 
penyu tersebut membahayakan populasi sebagai hewan yang dilindungi. Dari 37 kali towing, tertangkap 5 ekor penyu hijau (Chelonia mydas) ukuran panjang antara 40 sampai dengan $63 \mathrm{~cm}$ dalam keadaan hidup dan tidak cacat pada trawlyang tidak dilengkapi TEDs type super shooter. Sedangkan pada trawl yang dilengkapi TEDs type super shooter tidak seekor penyu pun tertangkap. Ini menunjukkan bahwa TEDs type super shooter efektif $100 \%$ meloloskan penyu.

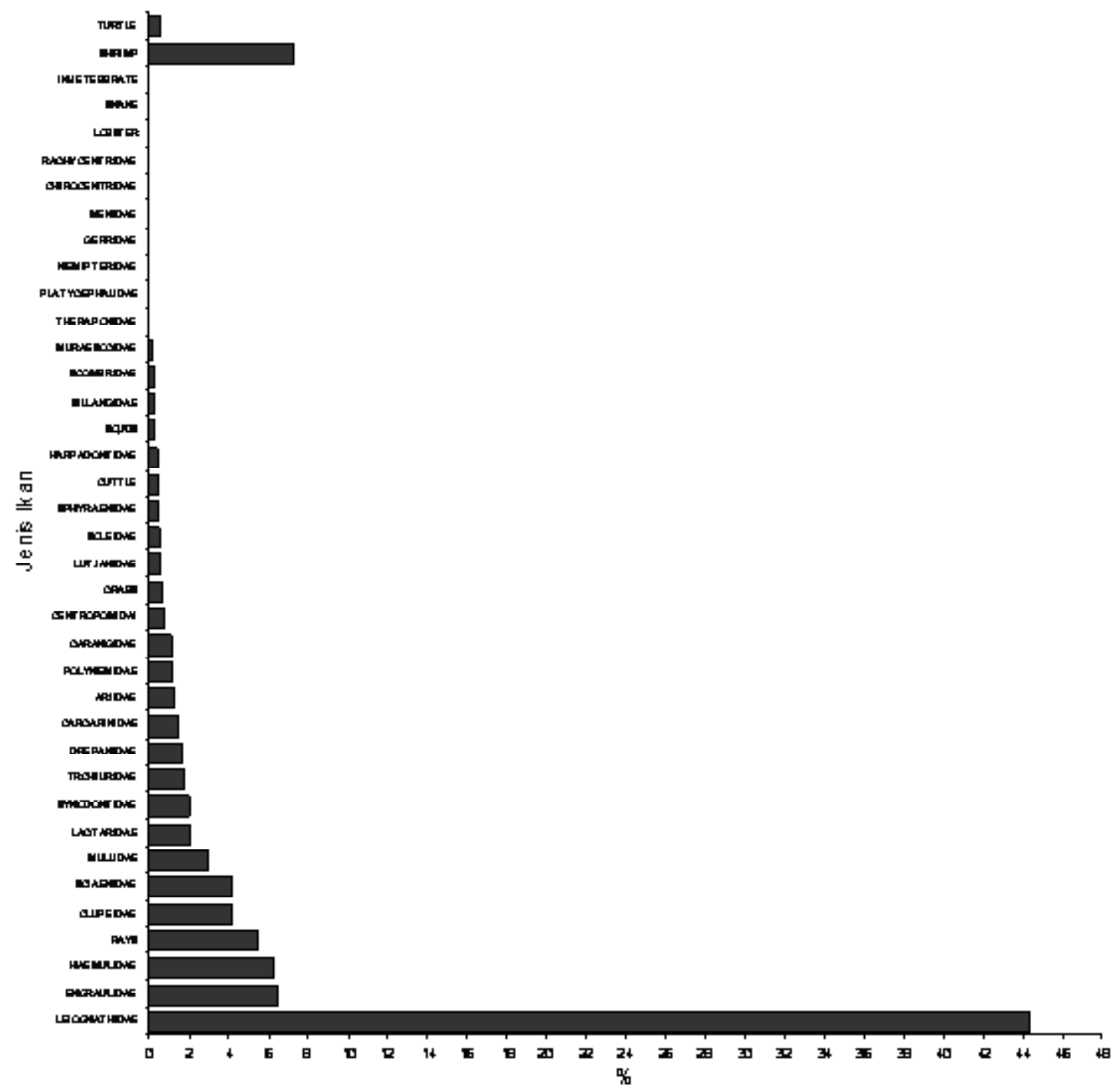

Gambar 8. Komposisi jenis hasil tangkapan selama ujicoba.

Figure 8. Catch composition during fishing trial

Penyu tertangkap pada operasi trawl di perairan Arafura dilepas kembali ke laut dalam keadaan hidup.

\section{Buangan (Discards)}

Buangan adalah sebagian atau seluruh dari hasil tangkapan samping yang dibuang atau dikembalikan ke laut baik dalam keadaan hidup atau mati. Buangan berdampak terhadap lingkungan dan ekonomi (Pascoe, 1997) karena buangan tersebut terdiri atas spesies sasaran dan bukan sasaran yaitu ikan ukuran kecil dan ikan muda (yuwana) di mana tidak mempunyai nilai komersil. Pada umumnya buangan berupa yuwana dan ikan-ikan kecil tidak dapat bertahan hidup (Chopin et al., 1995; Kaiser \& Spencer, 1995; Cher \& Gordon, 1997 dalam Pascoe, 1997). Dibuang yuwana dari spesies sasaran dan bukan sasaran mengakibatkan terjadi penurunan populasi (Savile, 1980 dalam Pascoe, 1997). Selain itu, juga berdampak hilang pendapatan masa mendatang tidak hanya bagi nelayan pembuang tetapi juga nelayan lain yang memanfaatkan yuwana tersebut sebagai 
Tabel 2. Tangkapan udang dari traw/tanpa TEDs type super shooterselama uji coba dan yang dilengkapi dengan TEDs type super shooter

Table 2. Shrimp catch of trawl unequiped and equiped by TEDs type super shooter

\begin{tabular}{|c|c|c|c|c|c|c|}
\hline \multirow[t]{2}{*}{$\begin{array}{c}\text { No. } \\
\text { Towing }\end{array}$} & \multicolumn{3}{|c|}{$\begin{array}{c}\text { Hasil tangkapan } 1 \text { trawl tanpa TEDs/ } \\
\text { Catch per towing without TEDs } \\
\text { (kg per towing) }\end{array}$} & \multicolumn{3}{|c|}{$\begin{array}{c}\text { Hasil tangkapan } 1 \text { trawl dengan TEDs/ } \\
\text { Catch per towing with TEDs } \\
\text { (kg per towing) }\end{array}$} \\
\hline & Ikan/Fish & Udang/Shrimp & Total & Ikan/Fish & Udang/Shrimp & Total \\
\hline 1 & 187,8 & 21,8 & 209,6 & 125,3 & 18,0 & 143,3 \\
\hline 2 & 205,9 & 24,4 & 230,3 & 112,3 & 17,2 & 129,5 \\
\hline 3 & 180,9 & 14,3 & 195,2 & 119,3 & 13,9 & 133,1 \\
\hline 4 & 325,0 & 12,9 & 337,9 & 170,0 & 8,2 & 178,2 \\
\hline 5 & 335,6 & 16,9 & 352,5 & 207,0 & 13,6 & 220,6 \\
\hline 6 & 415,1 & 29,7 & 444,8 & 213,3 & 21,5 & 234,8 \\
\hline 7 & 575,5 & 15,6 & 591,1 & 368,0 & 11,4 & 379,4 \\
\hline 8 & 255,5 & 24,6 & 280,1 & 138,1 & 15,7 & 153,8 \\
\hline 9 & 290,3 & 25,1 & 315,4 & 100,7 & 16,2 & 116,9 \\
\hline 10 & 404,1 & 20,6 & 424,7 & 196,7 & 18,2 & 214,9 \\
\hline 11 & 486,5 & 24,1 & 510,6 & 342,9 & 16,9 & 359,8 \\
\hline 12 & 648,5 & 19,3 & 667,8 & 411,8 & 17,8 & 429,5 \\
\hline 13 & 451,0 & 15,4 & 466,4 & 245,4 & 12,0 & 257,4 \\
\hline 14 & 391,0 & 8,9 & 399,9 & 218,0 & 7,0 & 225,0 \\
\hline 15 & 429,0 & 20,8 & 449,8 & 226,0 & 15,1 & 241,1 \\
\hline 16 & 378,4 & 18,7 & 397,1 & 262,5 & 14,1 & 276,6 \\
\hline 17 & 441,2 & 24,3 & 465,5 & 298,6 & 20,0 & 318,6 \\
\hline 18 & 724,4 & 32,5 & 756,9 & 407,2 & 24,6 & 431,8 \\
\hline 19 & 312,8 & 19,5 & 332,3 & 222,9 & 12,8 & 235,7 \\
\hline 20 & 543,6 & 29,1 & 572,7 & 300,6 & 20,2 & 320,8 \\
\hline 21 & 199,7 & 14,3 & 214,0 & 180,0 & 11,8 & 191,8 \\
\hline 22 & 268,3 & 19,7 & 288,0 & 198,5 & 13,3 & 211,8 \\
\hline 23 & 316,9 & 20,3 & 337,2 & 233,7 & 16,5 & 250,2 \\
\hline 24 & 414,7 & 37,1 & 451,8 & 279,5 & 30,8 & 310,3 \\
\hline 25 & 160,8 & 12,4 & 173,2 & 110,3 & 9,1 & 119,4 \\
\hline 26 & 300,7 & 25,1 & 325,8 & 127,7 & 20,1 & 147,8 \\
\hline 27 & 410,1 & 11,8 & 421,9 & 200,2 & 9,4 & 209,6 \\
\hline 28 & 176,5 & 27,1 & 203,6 & 90,8 & 20,7 & 111,5 \\
\hline 29 & 500,9 & 38,8 & 539,7 & 311,6 & 31,2 & 342,8 \\
\hline 30 & 175,3 & 21,8 & 197,1 & 120,1 & 16,4 & 136,5 \\
\hline 31 & 378,9 & 22,1 & 401,0 & 297,6 & 15,5 & 313,1 \\
\hline 32 & 190,4 & 18,7 & 209,1 & 157,1 & 15,0 & 172,1 \\
\hline 33 & 430,8 & 27,4 & 458,2 & 260,5 & 19,1 & 279,6 \\
\hline 34 & 186,7 & 15,5 & 202,2 & 110,8 & 12,6 & 123,4 \\
\hline 35 & 231,6 & 19,5 & 251,1 & 140,7 & 14,0 & 154,7 \\
\hline 36 & 490,1 & 36,3 & 526,4 & 298,5 & 30,4 & 328,9 \\
\hline 37 & 164,4 & 17,1 & 181,5 & 100,2 & 10,2 & 110,4 \\
\hline $\begin{array}{c}\text { Rata-rata/ } \\
\text { Average }\end{array}$ & 350,8 & 21,7 & 372,5 & 213,6 & 17,7 & 230,1 \\
\hline
\end{tabular}

spesies sasaran jika spesies tersebut mencapai ukuran komersil.

Buangan dikurangi untuk memperkecil kerugiankerugian masa kini dan masa mendatang yang lebih besar. Pengurangan dapat dilakukan dengan pengurangan hasil tangkapan samping. Program FAO dalam Code of Conduct for Responsible Fisheries menekankan perlu diambil langkah-langkah manajemen yang tepat untuk mengurangi hasil tangkapan yang dibuang dan mengurangi dampak negatif terhadap spesies-spesies yang terancam punah (FAO, 1995b). FAO menghimbau perlu mempromosikan pengembangan dan penggunaan alat tangkap yang mampu mengurangi hasil tangkapan samping dan buangan (FAO, 1995b). Hasil penelitian menunjukkan bahwa jumlah buangan pada trawl udang mencapai 95,91\% dari total hasil tangkapan samping (Tabel 5). 
Tabel 3. Hasil tangkapan samping ke-2 jenis traw/selama uji coba

Table 3. By catch of trawl for fishing experinemt

\begin{tabular}{|c|c|c|c|c|c|c|}
\hline \multirow[t]{2}{*}{$\begin{array}{c}\text { No. } \\
\text { Towing }\end{array}$} & \multicolumn{3}{|c|}{$\begin{array}{c}\text { Hasil tangkapan } 1 \text { trawl tanpa TEDs/ } \\
\text { Catch per towing without TEDs } \\
\text { (kg per towing) }\end{array}$} & \multicolumn{3}{|c|}{$\begin{array}{c}\text { Hasil tangkapan } 1 \text { trawl dengan TEDs/ } \\
\text { Catch per towing with TEDs } \\
\text { (kg per towing) }\end{array}$} \\
\hline & Ikan/Fish & Udang/Shrimp & Total & Ikan/Fish & Udang/Shrimp & Total \\
\hline 1 & 187,8 & 21,8 & 209,6 & 125,3 & 18,0 & 143,3 \\
\hline 2 & 205,9 & 24,4 & 230,3 & 112,3 & 17,2 & 129,5 \\
\hline 3 & 180,9 & 14,3 & 195,2 & 119,3 & 13,9 & 133,1 \\
\hline 4 & 325,0 & 12,9 & 337,9 & 170,0 & 8,2 & 178,2 \\
\hline 5 & 335,6 & 16,9 & 352,5 & 207,0 & 13,6 & 220,6 \\
\hline 6 & 415,1 & 29,7 & 444,8 & 213,3 & 21,5 & 234,8 \\
\hline 7 & 575,5 & 15,6 & 591,1 & 368,0 & 11,4 & 379,4 \\
\hline 8 & 255,5 & 24,6 & 280,1 & 138,1 & 15,7 & 153,8 \\
\hline 9 & 290,3 & 25,1 & 315,4 & 100,7 & 16,2 & 116,9 \\
\hline 10 & 404,1 & 20,6 & 424,7 & 196,7 & 18,2 & 214,9 \\
\hline 11 & 486,5 & 24,1 & 510,6 & 342,9 & 16,9 & 359,8 \\
\hline 12 & 648,5 & 19,3 & 667,8 & 411,8 & 17,8 & 429,5 \\
\hline 13 & 451,0 & 15,4 & 466,4 & 245,4 & 12,0 & 257,4 \\
\hline 14 & 391,0 & 8,9 & 399,9 & 218,0 & 7,0 & 225,0 \\
\hline 15 & 429,0 & 20,8 & 449,8 & 226,0 & 15,1 & 241,1 \\
\hline 16 & 378,4 & 18,7 & 397,1 & 262,5 & 14,1 & 276,6 \\
\hline 17 & 441,2 & 24,3 & 465,5 & 298,6 & 20,0 & 318,6 \\
\hline 18 & 724,4 & 32,5 & 756,9 & 407,2 & 24,6 & 431,8 \\
\hline 19 & 312,8 & 19,5 & 332,3 & 222,9 & 12,8 & 235,7 \\
\hline 20 & 543,6 & 29,1 & 572,7 & 300,6 & 20,2 & 320,8 \\
\hline 21 & 199,7 & 14,3 & 214,0 & 180,0 & 11,8 & 191,8 \\
\hline 22 & 268,3 & 19,7 & 288,0 & 198,5 & 13,3 & 211,8 \\
\hline 23 & 316,9 & 20,3 & 337,2 & 233,7 & 16,5 & 250,2 \\
\hline 24 & 414,7 & 37,1 & 451,8 & 279,5 & 30,8 & 310,3 \\
\hline 25 & 160,8 & 12,4 & 173,2 & 110,3 & 9,1 & 119,4 \\
\hline 26 & 300,7 & 25,1 & 325,8 & 127,7 & 20,1 & 147,8 \\
\hline 27 & 410,1 & 11,8 & 421,9 & 200,2 & 9,4 & 209,6 \\
\hline 28 & 176,5 & 27,1 & 203,6 & 90,8 & 20,7 & 111,5 \\
\hline 29 & 500,9 & 38,8 & 539,7 & 311,6 & 31,2 & 342,8 \\
\hline 30 & 175,3 & 21,8 & 197,1 & 120,1 & 16,4 & 136,5 \\
\hline 31 & 378,9 & 22,1 & 401,0 & 297,6 & 15,5 & 313,1 \\
\hline 32 & 190,4 & 18,7 & 209,1 & 157,1 & 15,0 & 172,1 \\
\hline 33 & 430,8 & 27,4 & 458,2 & 260,5 & 19,1 & 279,6 \\
\hline 34 & 186,7 & 15,5 & 202,2 & 110,8 & 12,6 & 123,4 \\
\hline 35 & 231,6 & 19,5 & 251,1 & 140,7 & 14,0 & 154,7 \\
\hline 36 & 490,1 & 36,3 & 526,4 & 298,5 & 30,4 & 328,9 \\
\hline 37 & 164,4 & 17,1 & 181,5 & 100,2 & 10,2 & 110,4 \\
\hline $\begin{array}{c}\text { Rata-rata/ } \\
\text { Average }\end{array}$ & 350,8 & 21,7 & 372,5 & 213,6 & 17,7 & 230,1 \\
\hline
\end{tabular}


Tabel 3. Hasil tangkapan samping ke-2 jenis traw/selama uji coba Table 3. By catch of trawl for fishing experinemt

\begin{tabular}{|c|c|c|c|c|}
\hline \multirow[t]{2}{*}{ No. } & \multirow{2}{*}{$\begin{array}{r}\text { Hasil tangkapan trawl non } \\
\text { TEDs net/Catch of } \\
\text { trawl without TEDs } \\
(\mathrm{kg})\end{array}$} & \multirow{2}{*}{$\begin{array}{c}\text { Hasil tangkapan trawl dengan } \\
\text { TEDs/Catch of trawl } \\
\text { with TEDs }(\mathrm{kg})\end{array}$} & \multicolumn{2}{|c|}{$\begin{array}{c}\text { Hasil tangkapan samping } \\
\text { yang lolos/ } \\
\text { By catch of trawl escaped }\end{array}$} \\
\hline & & & kg & $\%$ \\
\hline 1 & 187,8 & 125,3 & 62,6 & 33,3 \\
\hline 2 & 205,9 & 112,3 & 93,6 & 45,5 \\
\hline 3 & 180,9 & 119,3 & 61,7 & 34,1 \\
\hline 4 & 325,0 & 170,0 & 155,0 & 47,7 \\
\hline 5 & 335,6 & 207,0 & 128,6 & 38,3 \\
\hline 6 & 415,1 & 213,3 & 201,8 & 48,6 \\
\hline 7 & 575,5 & 368,0 & 207,5 & 36,1 \\
\hline 8 & 255,5 & 138,1 & 117,4 & 45,9 \\
\hline 9 & 290,3 & 100,7 & 189,6 & 65,3 \\
\hline 10 & 404,1 & 196,7 & 207,4 & 51,3 \\
\hline 11 & 486,5 & 342,9 & 143,6 & 29,5 \\
\hline 12 & 648,5 & 411,8 & 236,8 & 36,5 \\
\hline 13 & 451,0 & 245,4 & 205,6 & 45,6 \\
\hline 14 & 391,0 & 218,0 & 173,0 & 44,2 \\
\hline 15 & 429,0 & 226,0 & 203,0 & 47,3 \\
\hline 16 & 378,4 & 262,5 & 115,9 & 30,6 \\
\hline 17 & 441,2 & 298,6 & 142,6 & 32,3 \\
\hline 18 & 724,4 & 407,2 & 317,2 & 43,8 \\
\hline 19 & 312,8 & 222,9 & 89,9 & 28,7 \\
\hline 20 & 543,6 & 300,6 & 243,0 & 44,7 \\
\hline 21 & 199,7 & 180,0 & 19,7 & 9,9 \\
\hline 22 & 268,3 & 198,5 & 69,8 & 26,0 \\
\hline 23 & 316,9 & 233,7 & 83,2 & 26,3 \\
\hline 24 & 414,7 & 279,5 & 135,2 & 32,6 \\
\hline 25 & 160,8 & 110,3 & 50,5 & 31,4 \\
\hline 26 & 300,7 & 127,7 & 173,0 & 57,5 \\
\hline 27 & 410,1 & 200,2 & 209,9 & 51,2 \\
\hline 28 & 176,5 & 90,8 & 85,7 & 48,6 \\
\hline 29 & 500,9 & 311,6 & 189,3 & 37,8 \\
\hline 30 & 175,3 & 120,1 & 55,2 & 31,5 \\
\hline 31 & 378,9 & 297,6 & 81,3 & 21,5 \\
\hline 32 & 190,4 & 157,1 & 33,3 & 17,5 \\
\hline 33 & 430,8 & 260,5 & 170,3 & 39,5 \\
\hline 34 & 186,7 & 110,8 & 75,9 & 40,7 \\
\hline 35 & 231,6 & 140,7 & 90,9 & 39,2 \\
\hline 36 & 490,1 & 298,5 & 191,6 & 39,1 \\
\hline 37 & 164,4 & 100,2 & 64,2 & 39,1 \\
\hline $\begin{array}{c}\text { Rata-rata/ } \\
\text { Average }\end{array}$ & 350,78 & 213,63 & 137,15 & 39,10 \\
\hline
\end{tabular}


Tabel 4. Persentase hasil tangkapan samping terhadap tangkapan udang pada traw/tanpa TEDs type super shooter dan trawlyang dilengkapi TEDs type super shooter

Table 4. Percentage of by catch and shrimp on trawl unequiped and equiped by TEDs type super shooter

\begin{tabular}{|c|c|c|c|c|c|c|c|c|}
\hline \multirow[b]{2}{*}{ No. Towing } & \multicolumn{4}{|c|}{ Trawl tanpa TEDs/Trawl without TEDs } & \multicolumn{4}{|c|}{ Trawl dengan TEDs/Trawl with TEDs } \\
\hline & $\begin{array}{c}\text { lkan/ } \\
\text { Fish (kg) }\end{array}$ & $\begin{array}{c}\text { Udang/ } \\
\text { Shrimp (kg) }\end{array}$ & Total $(\mathbf{k g})$ & $\begin{array}{c}\text { Hasil tangkapan } \\
\text { samping/ } \\
\text { By catch }(\%)\end{array}$ & $\begin{array}{l}\text { Ikan/ } \\
\text { Fish } \\
\text { (kg) }\end{array}$ & $\begin{array}{l}\text { Udang/ } \\
\text { Shrimp } \\
\text { (kg) }\end{array}$ & $\begin{array}{c}\text { Total } \\
\mathbf{k g})\end{array}$ & $\begin{array}{c}\text { Hasil tangkapan } \\
\text { samping/ } \\
\text { By catch }(\%)\end{array}$ \\
\hline 1 & 187,8 & 21,8 & 209,6 & 89,6 & 125,3 & 18,0 & 143,3 & 87,4 \\
\hline 2 & 205,9 & 24,4 & 230,3 & 89,4 & 112,3 & 17,2 & 129,5 & 86,7 \\
\hline 3 & 180,9 & 14,3 & 195,2 & 92,7 & 119,3 & 13,9 & 133,1 & 89,6 \\
\hline 4 & 325,0 & 12,9 & 337,9 & 96,2 & 170,0 & 8,2 & 178,2 & 95,4 \\
\hline 5 & 335,6 & 16,9 & 352,5 & 95,2 & 207,0 & 13,6 & 220,6 & 93,9 \\
\hline 6 & 415,1 & 29,7 & 444,8 & 93,3 & 213,3 & 21,5 & 234,8 & 90,9 \\
\hline 7 & 575,5 & 15,6 & 591,1 & 97,4 & 368,0 & 11,4 & 379,4 & 97,0 \\
\hline 8 & 255,5 & 24,6 & 280,1 & 91,2 & 138,1 & 15,7 & 153,8 & 89,8 \\
\hline 9 & 290,3 & 25,1 & 315,4 & 92,1 & 100,7 & 16,2 & 116,9 & 86,1 \\
\hline 10 & 404,1 & 20,6 & 424,7 & 95,2 & 196,7 & 18,2 & 214,9 & 91,5 \\
\hline 11 & 486,5 & 24,1 & 510,6 & 95,3 & 342,9 & 16,9 & 359,8 & 95,3 \\
\hline 12 & 648,5 & 19,3 & 667,8 & 97,1 & 411,8 & 17,8 & 429,5 & 95,9 \\
\hline 13 & 451,0 & 15,4 & 466,4 & 96,7 & 245,4 & 12,0 & 257,4 & 95,3 \\
\hline 14 & 391,0 & 8,9 & 399,9 & 97,8 & 218,0 & 7,0 & 225,0 & 96,9 \\
\hline 15 & 429,0 & 20,8 & 449,8 & 95,4 & 226,0 & 15,1 & 241,1 & 93,7 \\
\hline 16 & 378,4 & 18,7 & 397,1 & 95,3 & 262,5 & 14,1 & 276,6 & 94,9 \\
\hline 17 & 441,2 & 24,3 & 465,5 & 94,8 & 298,6 & 20,0 & 318,6 & 93,7 \\
\hline 18 & 724,4 & 32,5 & 756,9 & 95,7 & 407,2 & 24,6 & 431,8 & 94,3 \\
\hline 19 & 312,8 & 19,5 & 332,3 & 94,1 & 222,9 & 12,8 & 235,7 & 94,6 \\
\hline 20 & 543,6 & 29,1 & 572,7 & 94,9 & 300,6 & 20,2 & 320,8 & 93,7 \\
\hline 21 & 199,7 & 14,3 & 214,0 & 93,3 & 180,0 & 11,8 & 191,8 & 93,8 \\
\hline 22 & 268,3 & 19,7 & 288,0 & 93,2 & 198,5 & 13,3 & 211,8 & 93,7 \\
\hline 23 & 316,9 & 20,3 & 337,2 & 94,0 & 233,7 & 16,5 & 250,2 & 93,4 \\
\hline 24 & 414,7 & 37,1 & 451,8 & 91,8 & 279,5 & 30,8 & 310,3 & 90,1 \\
\hline 25 & 160,8 & 12,4 & 173,2 & 92,8 & 110,3 & 9,1 & 119,4 & 92,4 \\
\hline 26 & 300,7 & 25,1 & 325,8 & 92,3 & 127,7 & 20,1 & 147,8 & 86,4 \\
\hline 27 & 410,1 & 11,8 & 421,9 & 97,2 & 200,2 & 9,4 & 209,6 & 95,5 \\
\hline 28 & 176,5 & 27,1 & 203,6 & 86,7 & 90,8 & 20,7 & 111,5 & 81,4 \\
\hline 29 & 500,9 & 38,8 & 539,7 & 92,8 & 311,6 & 31,2 & 342,8 & 90,9 \\
\hline 30 & 175,3 & 21,8 & 197,1 & 88,9 & 120,1 & 16,4 & 136,5 & 88,0 \\
\hline 31 & 378,9 & 22,1 & 401,0 & 94,5 & 297,6 & 15,5 & 313,1 & 95,0 \\
\hline 32 & 190,4 & 18,7 & 209,1 & 91,1 & 157,1 & 15,0 & 172,1 & 91,3 \\
\hline 33 & 430,8 & 27,4 & 458,2 & 94,0 & 260,5 & 19,1 & 279,6 & 93,2 \\
\hline 34 & 186,7 & 15,5 & 202,2 & 92,3 & 110,8 & 12,6 & 123,4 & 89,8 \\
\hline 35 & 231,6 & 19,5 & 251,1 & 92,2 & 140,7 & 14,0 & 154,7 & 91,0 \\
\hline 36 & 490,1 & 36,3 & 526,4 & 93,1 & 298,5 & 30,4 & 328,9 & 90,8 \\
\hline 37 & 164,4 & 17,1 & 181,5 & 90,6 & 100,2 & 10,2 & 110,4 & 90,8 \\
\hline $\begin{array}{c}\text { Rata-rata/ } \\
\text { Aveage }\end{array}$ & 350,8 & 21,7 & 372,5 & 93,5 & 213,6 & 16,5 & 230,1 & 92,0 \\
\hline
\end{tabular}


Tabel 5. Jumlah buangan pada trawludang

Table 5. Discards on shrimp trawl

\begin{tabular}{|c|c|c|c|c|}
\hline $\begin{array}{l}\text { No. } \\
\text { Towing }\end{array}$ & $\begin{array}{c}\text { Hasil tangkapan } \\
\text { samping/By catch } \\
(\mathrm{kg})\end{array}$ & $\begin{array}{c}\text { Hasil tangkapan samping } \\
\text { Dimanfaatkan/By catch is used } \\
(\mathrm{kg})\end{array}$ & $\begin{array}{l}\text { Dibuang/ } \\
\text { Discards } \\
(\mathrm{kg})\end{array}$ & $\%$ \\
\hline 1 & 313,1 & 16 & 297,1 & 94,89 \\
\hline 2 & 318,2 & 12 & 306,2 & 96,23 \\
\hline 3 & 300,2 & 23 & 277,2 & 92,34 \\
\hline 4 & 495 & 18 & 477 & 96,36 \\
\hline 5 & 542,6 & 22 & 520,6 & 95,95 \\
\hline 6 & 628,4 & 17 & 611,4 & 97,29 \\
\hline 7 & 943,5 & 43 & 900,5 & 95,44 \\
\hline 8 & 393,6 & 10 & 383,6 & 97,46 \\
\hline 9 & 391 & 21 & 370 & 94,63 \\
\hline 10 & 600,8 & 32 & 568,8 & 94,67 \\
\hline 11 & 829,4 & 37 & 792,4 & 95,54 \\
\hline 12 & 1060,3 & 29 & 1031,3 & 97,26 \\
\hline 13 & 696,4 & 25 & 671,4 & 96,41 \\
\hline 14 & 609 & 40 & 569 & 93,43 \\
\hline 15 & 655 & 13 & 642 & 98,02 \\
\hline 16 & 640,9 & 19 & 621,9 & 97,04 \\
\hline 17 & 739,8 & 44 & 695,8 & 94,05 \\
\hline 18 & 1131,6 & 28 & 1103,6 & 97,53 \\
\hline 19 & 535,7 & 14 & 521,7 & 97,39 \\
\hline 20 & 844,2 & 21 & 823,2 & 97,51 \\
\hline 21 & 379,7 & 16 & 363,7 & 95,79 \\
\hline 22 & 466,8 & 27 & 439,8 & 94,22 \\
\hline 23 & 550,6 & 41 & 509,6 & 92,55 \\
\hline 24 & 694,2 & 13 & 681,2 & 98,13 \\
\hline 25 & 271,1 & 8 & 263,1 & 97,05 \\
\hline 26 & 428,4 & 19 & 409,4 & 95,56 \\
\hline 27 & 610,3 & 15 & 595,3 & 97,54 \\
\hline 28 & 267,3 & 17 & 250,3 & 93,64 \\
\hline 29 & 812,5 & 42 & 770,5 & 94,83 \\
\hline 30 & 295,4 & 9 & 286,4 & 96,95 \\
\hline 31 & 676,5 & 21 & 655,5 & 96,90 \\
\hline 32 & 347,5 & 10 & 337,5 & 97,12 \\
\hline 33 & 691,3 & 16 & 675,3 & 97,69 \\
\hline 34 & 297,5 & 7 & 290,5 & 97,65 \\
\hline 35 & 372,3 & 19 & 353,3 & 94,90 \\
\hline 36 & 788,6 & 54 & 734,6 & 93,15 \\
\hline 37 & 264,6 & 12 & 252,6 & 95,46 \\
\hline $\begin{array}{c}\text { Rata-rata/ } \\
\text { Average }\end{array}$ & 564,41 & 22,43 & 541,98 & 95,91 \\
\hline
\end{tabular}




\section{KESIMPULAN DAN SARAN}

Dari hasil riset ini, dapat disimpulkan bahwa:

1. Pemasangan TEDs type super shooterpada trawl mampu mengurangi hasil tangkap sampingan ratarata $137,15 \mathrm{~kg}$ per towing dari rata-rata total 350,8 kg per towing (tingkat kelolosan=39,10\%).

2. Pemasangan TEDs type super shooterpada trawl juga mampu meloloskan semua penyu yang ikut tertangkap trawl (tingkat kelolosan=100\%).

3. Di sisi lain, pemasangan TEDs type super shooter juga mengurangi hasil tangkapan sasaran (udang) dengan jumlah yang cukup tinggi yaitu mencapai rata-rata $4,0 \mathrm{~kg}$ per towing dari rata-rata hasil tangkapan trawl 21,7 kg per towing (tingkat kelolosan=18,43\%).

4. Diperlukan riset lebih mendalam mengenai desain dan konstruksi serta cara pemasangan TEDs type suoper shooter yang sesuai bagi traw/udang yang beroperasi di Indonesia sehingga tingkat kelolosan dapat dieliminir sampai dengan $<18,43 \%$.

\section{PERSANTUNAN}

Kegiatan dari hasil riset ujicoba TEDs type suoper shooter di perairan Arafura, T.A. 2003, di Balai Riset Perikanan Laut-Muara Baru, Jakarta.

\section{DAFTAR PUSTAKA}

Alverson, D., M. H. Freeberg, S. A. Murawski, \& J. G. Pope. 1994. A global assessment of the fisheries bycatch and discards. FAO Fisheries Technical Paper No.339. F.A. Rome. 1994. Hal.1-32. 48-76. 155-189.

FAO. 1995a. Methodology manual: Measurement of fishing gear selectivity. FAO. Rome. Hal.4-24-427.

1995b. Code of conduct for responsible fisheries. FAO. Rome. Hal.13-14. 32-334.

Nedelec, Claude, \& J. Prado. 1990. Definition and classification of fishing gear categories. FAO. Fisheries Technical Paper No.222. Rev.1. FAO Rome. 1990. Hal.25-29.

Pascoe, S. 1997. By catch management and the economic of discarding. FAO Fisheries Technical Paper No.370. FAO. Rome. 1997. Hal.1-27. 8796.

Taylor, C. W., A. F. Sierra, J. F. Mitchell, \& R. C. Sawyer. 1985. Construction and installation instructions for the trawling efficiency device. NOAA Technical Memorandum NMFS-SEFC-71. US Department of Commerce. NOAA. NMFS-SEFC. Missisipi Laboratories. Pascagola Facility. 1985. 22 hal.

Watson, J. W., Michell, \& A. Shah. 1986, Trawling efficiency devices: A new concept for selective shrimp trawling gear. Marine Fisheries Rev. 48 (1). 1986. 9 hal. 